It could not be expected that forestry work out in the jungles could be carried on without danger. Four forest rangers and guards and a number of Chinese employed in forest work were killed during the year, and saw-mills and departmental buildings and several hundred tons of sawn timber were burnt. A number of forest officers were taken from their normal duty, so that their knowledge of the jungles could be used in the present military operations; this has come hard on the department, and necessitated the curtailing of important work. In connexion with the maintenance of the export timber trade, the report says: "The value of timber exported to the United Kingdom again showed a spectacular increase. Much of this timber was in the form of mixed light hardwoods which are largely used in the United Kingdom as a substitute for soft woods normally obtained from hard currency areas". Malaya came fifth in this type of export to the United Kingdom. It appears that the state of the country and the difficulty of protecting the men employed in the old methods of hand-logging so prevalent in the forests of the East and Far East are bringing about logging by tractor ; it is said that a demonstration in Selangor proved conclusively that extraction costs could be greatly reduced and did much to dispel fears that tractors might not be able to handle timber.

It is impossible to review the report in all its details of the work done, including the carrying on of research work of considerable importance; but the Bangkok Conference is worthy of mention. The inaugural session of the Forestry and Forest Products Commission for Asia and the Pacific was held at Bangkok during October 9-18, with Mr. Edwards leading the British delegation. As he says, "the existence of a Commission for this part of the world fulfils a definite want and will provide a convenient medium for the discussion of common problems". A great deal of useful work was got through at the Conference; but the warning note was struck that "the success of the Commission will very largely depend on how far Member Governments find themselves able to implement the recommendations made at Mysore and Bangkok". Past experience of similar such commissions teaches that this one will mainly stand or fall on the extent to which government administrations realize how their property can benefit economically as a result of the work accomplished.

\section{BODY TEMPERATURES IN NESTLING WESTERN GULLS}

$\mathrm{A}^{\mathrm{L}}$

THOUGH it has been known for more than half a century that some kinds of young birds have only limited capacity to control body temperature, data on the ontogenetic development of temperature regulation are available for few species of wild birds, either altricial or precocial.

In June 1950 advantage was taken of the opportunity afforded by a large breeding colony of western gulls (Larus occidentalis wymani) at Santa Barbara Island, and the body temperatures of more than sixty nestlings were taken by G. A. Bartholomew, jun., Wm. R. Dawson and R. D. Collyer (Condor, 54, No. 1 ; January-February 1952).

The cloacal temperatures of the birds and the air temperatures were measured to the nearest tenth of a degree (centigrade) with a mercury thermometer. There were no means of weighing the birds, and, as an indication of relative age, a simple linear measurement was used, namely, from the tip of bill to the end of the pygostyle with the bird in a prone extended position. Temperatures were determined in the middle of the day and again two to three hours after sunset. The birds measured ranged from individuals which were just hatching to those which were almost fully feathered.

Measurements showed that there is a statistically significant correlation between body temperatures and air temperatures. At all times body temperatures were far above those of the environment and, although air temperature varied through more than $13^{\circ} \mathrm{C}$, , a fluctuation of only slightly more than $6^{\circ} \mathrm{C}$. was observed even in the smallest class of gulls.

The fact that the lowest air temperatures occurred at night, which is also the time of minimal activity for the young gulls, made it difficult to assess under field conditions the relative effects of environmental temperature and the diurnal cycle of activity on body temperatures at night.

During the day-time the correlation between body length and body temperature was not significant. This lack of correlation suggests that even the smallest of the nestlings can regulate its temperature adequately in the range of day-time temperatures at which measurements were made. At night the correlation between body length and body temperature was stronger. Data did not indicate, however, whether the night-time body temperatures of the large nestlings were higher than those of the small ones because of a greater relative heat production or because of a smaller relative rate of heat loss associated with their lower surface-mass ratio.

Very small nestlings may compensate in part for their relatively large surface area by a behavioural response. At night in virtually every instance the smaller birds were found "huddling", two or three close together in well-sheltered sites. That the huddling response conserves heat in birds was previously shown by Kleiber and Winchester in 1933, who found that, by huddling together, baby domestic chicks can reduce their metabolic rates as much as 15 per cent.

During the day nestling gulls can supplement metabolic heat by the absorption of radiant energy. Should the heat of the sun become excessive, they may resort to shelter. Nearly all the western gull nests on Santa Barbara Island were at least partly shaded by rocks or vegetation. The sheltered location of young and eggs also afforded considerable protection from the wind. The newly hatched young remain in, or very close to, the nest, while the larger young are less sedentary and in consequence much more exposed to the elements.

During the afternoon the investigators found two "pipped" eggs which, because of their presence in the rookery, had not been incubated for the preceding forty-five minutes. The eggs were opened and cloacal temperatures of the young birds were measured. The hatchlings' temperatures were $32 \cdot 3^{\circ}$ and $33.8^{\circ} \mathrm{C}$. and the air temperature was $27^{\circ} \mathrm{C}$. The importance of radiant energy in furnishing heat was in this instance reduced by an overcast sky and the shelter supplied by tussocks of grass. These temperature measurements suggest that, in the western gull, as was also shown in the domestic chicken by Romanoff in 1941, some ability to regulate body temperature is present before hatching. 